\title{
Quantitative Analysis of Pregnancy-Associated Plasma Proteins in Human Placenta
}

\author{
Tsue-Ming Lin, Seymour P. Halbert, and David Kuefer \\ From the University of Miami School of Medicine, Department of Pediatrics, \\ Miami, Florida 33152
}

\begin{abstract}
A B S T R A C T By immunochemical methods and simultaneous measurements of several normal plasma proteins, human placenta was shown to contain elevated quantities of four pregnancy-associated plasma proteins (PAPP's). In the order of increasing amounts, PAPP-A, PAPP-C, PAPP-B, and human chorionic somatomammotropin (PAPP-D) all were present in placenta extracts in quantities greater than could be expected on the basis of their content of maternal blood. In sharp contrast, the placental content of pregnancy zone protein could be entirely accounted for by the maternal plasma present in the placenta.
\end{abstract}

All of the PAPP's appeared to be readily extractable from placental tissue with buffered saline, the large bulk of them being solubilized in the first extraction procedure. However, absorption studies indicated that appreciable quantities of the PAPP's were still present in the insoluble placental residue after 12 sequential extractions with saline. The chorioamniotic membranes were not significantly enriched in any of the PAPP's.

Immunochemical analysis of unwashed placental tissue extracts for the PAPP's, IgA, and IgM (maternal blood derived), as well as albumin and transferrin (maternal and fetal blood derived), permitted calculations to be made of the amount of blood and PAPP's in placenta. On the basis of these data, it was roughly estimated that a $400-\mathrm{g}$ placenta (wet weight) would occupy $312 \mathrm{ml}$ in volume, and would contain $144 \mathrm{ml}$ of blood. Of this blood, $36 \mathrm{ml}$ would be derived from the mother.

\section{INTRODUCTION}

Four distinct pregnancy-associated plasma proteins (PAPP's $)^{1}$ have been demonstrated in human pregnancy plasma by means of appropriately absorbed hyperimmune

\footnotetext{
Received for publication 1 August 1975 and in revised form 10 October 1975.

${ }^{1}$ Abbreviations used in this paper: E/M, extract/maternal plasma; HCS, human chorionic somatomammotropin; PAPP, pregnancy-associated plasma protein; PBS, phosphate-buffered saline; PZP, pregnancy zone protein.
}

antisera to late pregnancy plasma, by using sensitive gel diffusion methods $(1,2)$. These proteins appeared to be pregnancy-specific and gradually increased in concentration during human gestation (1-4). One of them, PAPP-D (mol wt, 20,000; pI 5.7) was identified as human chorionic somatomammotropin (HCS). ${ }^{2}$ Another, PAPP-C (mol wt, 110,000; pI 3.8), was shown to be identical to the pregnancy-specific $\beta_{1}$-glycoprotein SP1 of Bohn $(2,5,6)$. The other two: PAPP-A (mol wt, 750,000 ; pI 4.3) and PAPP-B appear to represent newly discovered proteins. In immunoelectrophoresis with Veronal-acetate buffer at $\mathrm{pH} 8.6$, both PAPP-A and HCS (PAPP-D) migrated as $\alpha_{2}$, while both PAPP-B and PAPP-C as $\beta_{1}$-globulins (2). They all decreased sharply after delivery, with half-lives of 3-4 days (PAPP-A), 1-2 days (PAPP-C), and $<1$ day for PAPP-B and HCS (7). In view of this, and their apparent absence in cord blood $(1,4)$, the present studies were carried out to obtain information regarding the possibility that the placenta might be the source of all of these proteins.

Another pregnancy-associated plasma protein, pregnancy zone protein (PZP), has been studied under eight other different names by many laboratories (8) : $\alpha_{2}$-pregnoglobulin, SP3, new serum $\alpha_{2}$-macroglobulin, PAG, $\mathrm{Pa} 1$, pregnancy-associated $\alpha_{2}$-globulin, $\mathrm{Xh}$, and $\mathrm{Xm}$. $\mathrm{PZP}$ is found at low levels in varying numbers of nonpregnant females and males, but it increases in concentration during gestation, as well as under other conditions (e.g., oral steroid hormone contraception and cancer) (9-12). PZP is physicochemically, as well as immunologically distinct from all the PAPP's (8). PZP also decreases after delivery, but at a much slower rate than the PAPP's $(7,13,14)$. Because of its association with pregnancy, the levels of $\mathrm{PZP}$ in placentae were also analyzed.

\section{METHODS}

Tissues. Human placentae were obtained from the delivery rooms at the University of Miami Medical Center.

'This hormone is also called "human placental lactogen" (HPL). 


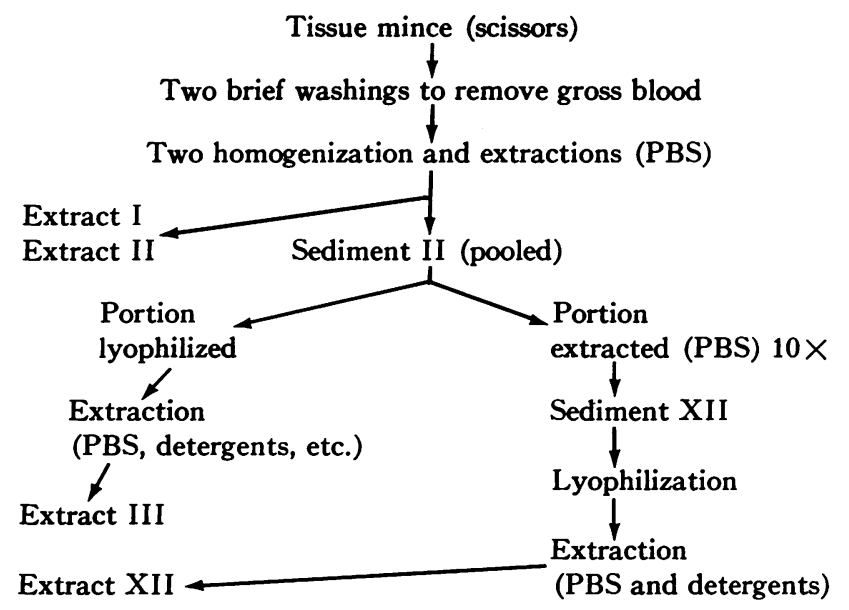

Figure 1 Placental tissue extraction procedure.

Each was washed rapidly twice with 4 liters of chilled 0.01 $M$ phosphate-buffered saline ( $\mathrm{PBS}, \mathrm{pH}$ 7.1) to remove gross blood from the surface and the superficial large vessels. They were trimmed of free membranes (chorionic and amniotic), weighed, measured for volume by fluid replacement, and stored at $-20^{\circ} \mathrm{C}$ until further processed. Maternal venous plasma samples from the same patients were collected on the day of delivery.

Extraction. As outlined in the flow diagram of Fig. 1, the placental tissue was minced, washed briefly, and homogenized thoroughly with PBS $(1 \mathrm{~g} / \mathrm{ml})$ at maximum speed in an ice bath (Omnimixer, DuPont Instruments, Sorvall Operations, Newtown, Conn.). After the homogenates were centrifuged at $78,000 \mathrm{~g}$ for $30 \mathrm{~min}$, the clear supernate (extract I) was harvested. The sediment was reextracted to obtain extract II.

The sediments were then pooled and divided into two portions. One portion was lyophilized, and aliquots of the dry powder were extracted at $100 \mathrm{mg}$ powder $/ \mathrm{ml}$ solution with PBS. In addition, more vigorous extraction procedures were used, including: 10 cycles of freezing and thawing; use of various detergents in $5 \mathrm{mM}$ EDTA and $5 \mathrm{mM}$ 2-mercaptoethanol, i.e., 5\% Triton X-100 (Rohm \& Haas Co., Philadelphia), 5\% Tween 80 (Atlas Chemical Industries, Inc., Wilmington, Del.), 2\% Lubrol WX, 2\% Lubrol PX (I. C. I./Organics/Inc., Providence, R. I.), 30\% butanol, and $1 \% \mathrm{Na}$ deoxycholate; and neuraminidase treatment $(1 \mathrm{mg} / \mathrm{ml}$, Clostridium perfringens; Worthington Biochemical Corp., Freehold, N. J.). Each of these extracts (III) was concentrated sixfold through lyophilization. The chemicals were purchased from various sources as described elsewhere (8).

The other portion of the sediment pool was repeatedly extracted and washed (10 more times) with 2-4 vol of PBS. The final sediment (XII) was lyophilized and subsequently further extracted by the vigorous procedures described above to obtain extracts XII.

The chorioamniotic membranes from these placentae were pooled and processed with PBS to obtain the membrane extract I, as described above for the placental tissue extraction. The sediment was reextracted with $2-4$ vol of PBS five more times, and the residue was lyophilized (sediment VI). The lyophilized powder was extracted with detergents, and the extracts were concentrated sixfold to obtain various membrane extracts VII.
Portions of whole placental tissue $(40 \mathrm{~g}$ each) were minced in the frozten state, and without the two brief washings they were homogenized with an equal volume of cold water, then lyophilized in a preweighed bottle. The resultant powder weighed $155 \mathrm{mg} / \mathrm{g}$ wet tissue and was designated "crude placental tissue powder."

Assays. Concentrations of the pregnancy-associated and other plasma proteins in the extracts and plasma were measured in duplicate or triplicate by the "rocket" electroimmunodiffusion, radial immunodiffusion methods and/or crossed-immunoelectrophoresis $(3,15)$.

Since the placental extracts unavoidably contained some maternal blood contamination, it was necessary to determine the proportion of the measured pregnancy proteins that were derived from this source. For this purpose, radial immunodiffusion measurements were also made of serum albumin and transferrin (derived from fetal and maternal circulation), as well as IgA and IgM (derived principally from the maternal circulation). The PAPP's have been found to be undetectable in the fetal circulation (cord serum) by gel diffusion methods (14). The assays for the normal plasma proteins were carried out with rabbit antisera to $\operatorname{IgA}, \operatorname{IgM}$, albumin, and transferrin from Behringwerke AG., MarburgLahn, West Germany).

The concentrations of these proteins were arbitrarily expressed as units per milliliter, with those in a reference pool of late pregnancy plasma being considered as $100 \mathrm{U} / \mathrm{ml}$. The protein content of the extracts were roughly estimated by absorption of light at $280 \mathrm{~nm}$ wavelength in a $1-\mathrm{cm}$ light path. $1 \mathrm{U}$ of absorbance was considered to represent approximately $1 \mathrm{mg} / \mathrm{ml}$ of protein concentration.

\section{RESULTS}

Saline extracts of placental tissue. Of the seven placentae processed individually, the wet weights ranged from 360 to $440 \mathrm{~g}$ and their average volume was 0.78 $\mathrm{ml} / \mathrm{g}$. The total protein contents of the first placental extracts varied from 14 to $24 \mathrm{mg} / \mathrm{ml}$ (mean 18) and from 4 to 15 for the second extracts (mean 7 ). The individual protein concentrations in each extract were related to the respective maternal plasma values and represented as ratios (extract/maternal plasma, E/M). This 
TABLE I

Average Concentrations of PAPP's and Normal Plasma Proteins in the First Placental Extracts and Their Respective Maternal Plasmas in Seven Patients at Delivery

\begin{tabular}{ccccccccc}
\hline \multirow{2}{*}{$\begin{array}{c}\text { Patient } \\
\text { no. }\end{array}$} & PAPP-A & PAPP-C & HPL & PZP & \multicolumn{1}{c}{ IgA } & IgM & Albumin & Transferrin \\
\cline { 2 - 9 } & & & & \multicolumn{1}{c}{$U / m l$} \\
1 & $18 / 80$ & $14 / 105$ & $2,960 / 100$ & $0.4 / 7$ & $2.1 / 126$ & $0.35 / 115$ & $5.7 / 117$ & $3.6 / 114$ \\
2 & $19 / 196$ & $12 / 82$ & $2,520 / 100$ & $0.4 / 76$ & $1.1 / 84$ & $0.25 / 54$ & $2.7 / 180$ & $2.4 / 156$ \\
3 & $16 / 121$ & $7 / 52$ & $2,950 / 36$ & $0.5 / 80$ & $2.4 / 180$ & $0.54 / 240$ & $3.3 / 138$ & $3.6 / 168$ \\
4 & $8 / 103$ & $9 / 132$ & $3,280 / 168$ & $0.4 / 116$ & $0.9 / 81$ & $0.25 / 140$ & $1.4 / 105$ & $1.2 / 117$ \\
5 & $15 / 60$ & $12 / 92$ & $1,960 / 100$ & $0.4 / 60$ & $0.6 / 84$ & $0.25 / 90$ & $4.5 / 118$ & $3.3 / 118$ \\
6 & $23 / 86$ & $8 / 94$ & $6,800 / 120$ & $0.4 / 15$ & $0.6 / 85$ & $0.25 / 78$ & $3.3 / 135$ & $1.9 / 99$ \\
7 & $26 / 64$ & $15 / 79$ & $4,720 / 120$ & $0.6 / 134$ & $1.2 / 117$ & $0.35 / 135$ & $4.4 / 102$ & $3.6 / 115$ \\
\hline
\end{tabular}

ratio for the normal plasma proteins furnished a guide to the extent of total or maternal blood contamination in the extracts. The results with the first placental extracts and maternal plasma are shown in Table I and Fig. 2. The ratios for albumin and transferrin averaged $2-3 \%$, indicating that each milliliter of extract was contaminated with $0.02-0.03 \mathrm{ml}$ of total plasma. On the other hand, the ratios for $\operatorname{IgA}$ and $\operatorname{IgM}$, which were mostly derived from the maternal circulation, showed values of $1 \%$ or less. Thus, of the proteins found in the placental

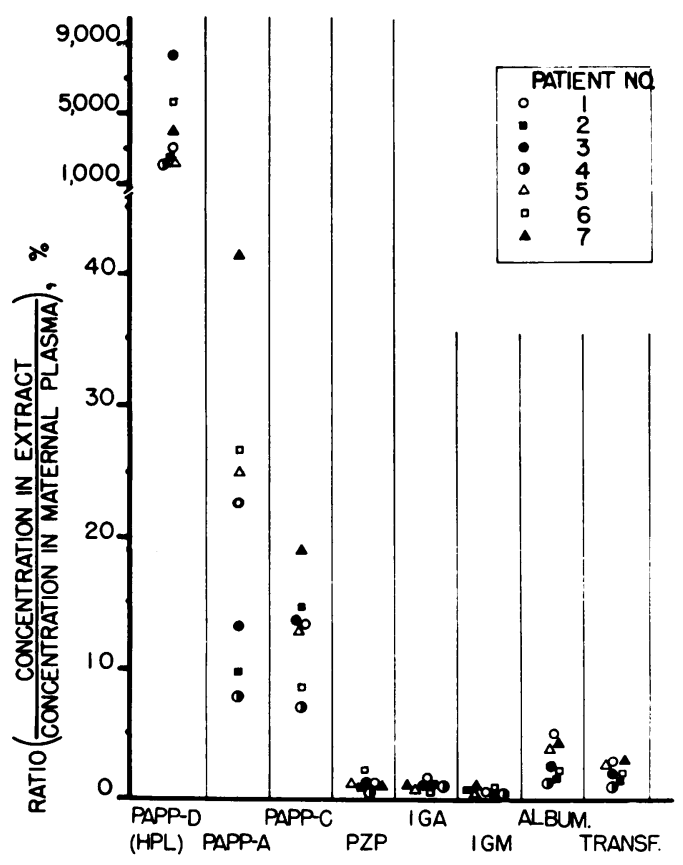

FIGURE 2 The ratios of pregnancy-associated and normal plasma protein concentrations in the first placental extracts to those in the maternal plasmas. extracts, only this latter small portion could be derived from the maternal plasma present there.

On this basis, it is clear that the observed concentrations of HCS (PAPP-D) present in the placental extracts were vastly greater (about 40 -fold) than could be accounted for by the maternal blood present there (see Fig. 2). Similarly, the concentrations of PAPP-A and PAPP-C were appreciably higher than that contributed by the maternal plasma in the extracts, with mean ratios of 21 and $12 \%$, respectively.

In sharp contrast, the PZP in the placental extracts were in the same proportions as the ratios found for IgA and IgM, clearly suggesting that all of the PZP in placenta was derived from the maternal circulation.

Because specific antiserum to PAPP-B is not yet available, this pregnancy protein was only analyzed in pools of maternal plasma and extracts by the crossed-immunoelectrophoretic method. With this technic, the PAPP-B ratio of the pooled first extract/pooled maternal serum was $29 \%$. For comparative purposes, the ratio for PAPP-A found in these pools at the same time was $16 \%$, in reasonable agreement with the average value in Fig. 2. No PAPP-B was detected in the last placental extracts (XII).

The concentrations of all the proteins studied in the second placental extracts were lower than those in the first extracts. However, in all cases the same trends observed in Fig. 2 were found. Again, the PZP present was all apparently derived from the maternal circulation. All of the subquent extracts (in III and XII) with PBS alone, detergents, etc. also revealed similar trends, but the values for the PAPP's in all the latter extracts were much lower. Analysis of the fluids from the two brief washings to remove gross blood from the placental minces indicated that no significant losses of the PAPP's from placental tissue occurred during this procedure, with the exception of HCS. 
Extracts of chorioamniotic membranes. The first PBS extract (I) of the pooled membranes showed a protein content of $5.7 \mathrm{mg} / \mathrm{ml}$, but the $\mathrm{E} / \mathrm{M}$ ratios for PAPP-A, PAPP-C and PZP were all close to those seen for the normal plasma proteins, all being less than $1 \%$ (Table II). Although the value for HCS was slightly elevated, it was dramatically less than those seen with the first placental extracts. The $E / M$ ratios for various proteins in the membrane extracts VII showed similar patterns to those in the first membrane extract, but at lower values. PAPP-B was not detected in any of the membrane extracts. Not unexpectedly, in terms of per unit dry weight of tissue, the membrane extracts contained less blood, but it was clear that the membranes were not appreciably enriched in any of the PAPP's, beyond that contributed by the maternal plasma.

Absorption of antibodies to $P A P P$ 's with insoluble placental and chorioamniotic membrane residues. The above findings that the tissue residue after 12 repeated extractions still yielded traces of the PAPP's upon further processing prompted antibody absorption tests to measure these proteins in the residues. For this purpose, varying amounts of lyophilized powders of the final insoluble placental sediment (XII) and chorioamniotic membrane sediment (VI) were dispersed into $1 \mathrm{ml}$ of anti-PAPP antiserum. The mixtures were incubated at $4^{\circ} \mathrm{C}$ overnight, clarified by centrifugation, then assayed for remaining anti-PAPP activity. As a control, insoluble powder of repeatedly extracted, nonpregnant human liver tissue residue was similarly treated. To serve as standard, twofold increasing amounts of lyophilized reference pregnancy plasma powder was mixed with antiserum and processed as above. All values were calculated for the same tissue dry weight basis $(60 \mathrm{mg} / \mathrm{ml}$ antiserum) for comparison.

The antiserum retained its full anti-PAPP's activity after treatment with human liver, as compared with the untreated antiserum. The chorioamniotic membrane sediment also did not reduce anti-PAPP-A and anti-PAPP-B and absorbed only negligible amounts of antiPAPP-C. It did reduce the anti-HCS content by an amount equivalent to that accomplished by $0.05 \mathrm{ml}$ reference pregnancy plasma. On the other hand, on the basis of its capacity to absorb antibodies, $60 \mathrm{mg}$ of the placental sediment powder (XII) contained PAPP-A, PAPP-C, PAPP-B, and HCS roughly equivalent to $0.08,0.08,0.75$, and $4.0 \mathrm{ml}$ of reference pregnancy plasma, respectively.

Tissue affinity for PAPP's. Although the above findings clearly demonstrate that placental tissue contained a higher content of all the PAPP's than was derived from the maternal plasma present in placenta, it does not necessarily indicate that the PAPP's were synthesized there. It is conceivable that they were produced in
TABLE II

PAPP Concentrations in Extracts of Human Chorioamniotic Membrane as Compared with That in the Maternal Plasma

\begin{tabular}{lcc}
\hline \multirow{2}{*}{\multicolumn{1}{c}{ Proteins }} & \multicolumn{2}{c}{ E/M ratio* } \\
\cline { 2 - 3 } & $\begin{array}{c}\text { Membrane } \\
\text { extract I }\end{array}$ & $\begin{array}{c}\text { Membrane } \\
\text { extract VII }\end{array}$ \\
\hline HCS (PAPP-D) & \multicolumn{2}{c}{$\%$} \\
PAPP-A & 5.2 & 24.7 \\
PAPP-C (SP1) & 0.7 & 1.8 \\
PZP & 0.8 & 1.2 \\
IgA & 0.3 & 0.5 \\
IgM & 0.9 & 0.8 \\
Albumin & 0.5 & 2.2 \\
Transferrin & 0.7 & 0.5 \\
& 0.8 & 0.5 \\
\hline
\end{tabular}

* Concentration in extracts/concentration in maternal plasma. ‡ Sixfold concentrate; therefore, these values should be divided by 6 for direct comparison with those shown for the membrane extract $I$. The values recorded are averages of those found for the various types of extraction procedures used, since they all yielded equivalent results.

other organs and became concentrated in placenta by various receptor substances, etc. As one approach to test this possibility, experiments were carried out to determine whether the placental and membrane insoluble residues could absorb PAPP's from pregnancy plasma, assuming that exhaustive extractions had freed most of the receptors. The powder of the insoluble placental residue (XII), chorioamniotic membrane residue (VI), human liver, and normal male plasma were each mixed with pregnancy plasma at $60 \mathrm{mg} / \mathrm{ml}$. After overnight incubation at $4^{\circ} \mathrm{C}$ and high-speed centrifugation, the clear supernates were assayed immunologically for PAPP activity. In no case was a decrease found of any of the PAPP's or of PZP.

Estimation of $P A P P^{\prime} s$ in unwashed placental tissue. All the above experiments were carried out with washed placental tissues to minimize the blood contamination and to facilitate quantitative immunoassay and analysis. For estimating the PAPP's and plasma concentrations in the whole placental tissue, unwashed specimens were more suitable. Therefore, some investigations were carried out on the crude placental tissue powder. Preliminary tests showed that varying the centrifugal force applied to saline suspensions of this powder from 6,000 to $160,000 \mathrm{~g}$ did not influence the yield of PAPP's or serum proteins. When $100 \mathrm{mg}$ of tissue powder in duplicate was extracted four times with $1.25 \mathrm{ml}$ of $\mathrm{PBS}$, the yield of PAPP's and normal serum proteins in the second extracts were approximately $10 \%$ those of the first extract. 
Those which could also be readily measured in the 3 rd and 4th extracts are represented in Fig. 3. It can be seen that rapidly decreasing yields were obtained, but that the PAPP levels decreased somewhat more slowly than did the serum proteins albumin and transferrin. The latter findings suggest that the PAPP's continued to be released from tissue sources, as compared to simple washing out of the plasma proteins.

In order to determine the total amount of the PAPP's and serum proteins present in crude placental tissue, varying quantities of the powder $(25-150 \mathrm{mg})$ in duplicate were extracted with $1 \mathrm{ml}$ of PBS overnight at $4^{\circ} \mathrm{C}$. By extrapolation of the values obtained to a theoretical $100 \%$ recovery of extract, it was estimated that $1 \mathrm{~g}$ wet weight of placental tissue contained amounts of readily extractable PAPP-A, PAPP-C, PZP, and HCS equivalent to the quantities present in $0.38,0.32,0.02$, and 116 $\mathrm{ml}$, respectively, of the reference pregnancy plasma pool. Direct determinations of the faint PAPP-B system could not be carried out with these extracts because of the excessive background staining.

Similar analyses of these extracts for albumin and transferrin showed that $1 \mathrm{~g}$ wet weight of placental tissue contained about $0.2 \mathrm{ml}$ of plasma. Measurements of $\operatorname{IgM}$ and $\operatorname{IgA}$ indicated that $0.05 \mathrm{ml}$ of this originated from the maternal circulation.

Antibody absorption studies were performed with antiPAPP antiserum, using this crude placental tissue powder, as described above with the insoluble placental residue. The results showed that $1 \mathrm{~g}$ wet weight of placenta was equivalent to $0.6,0.6,4.0$, and $>30 \mathrm{ml}$ of the reference pregnancy plasma pool for PAPP-A, PAPP-C, PAPP-B, and HCS, respectively.

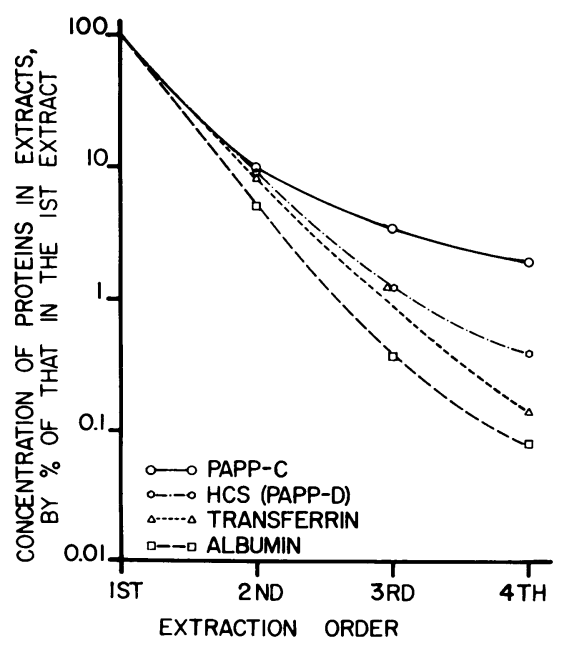

FIGURE 3 Mean concentration of two PAPP's and two normal plasma proteins in four sequential extracts of human placental tissue.

T-M. Lin. S. P. Halbert, and D. Kiefer

\section{DISCUSSION}

This study clearly demonstrated that all of the PAPP's are present in placenta in concentrations significantly greater than could be accounted for by the quantities derived from the maternal plasma in the placenta. In sharp contrast, the findings indicated that all of the PZP in placenta originated from its content of maternal blood. The failure to find PZP in even slightly increased amounts over the $\operatorname{IgM}$ and $\operatorname{Ig} \mathrm{A}$ concentrations in the placental extracts further suggested that this pregnancyassociated protein is not preferentially concentrated in the placenta by receptors, etc., to perform some local physiological function. A recent observation by Stimson and Blackstock indicates that PZP may be synthesized by leukocytes (16).

Although these observations do not necessarily indicate that the PAPP's are synthesized in placenta, other findings support this interpretation of the data: (a) all of the PAPP's rapidly disappeared from the maternal circulation after childbirth (7); $(b)$ immunofluorescence studies showed that PAPP-A, PAPP-C, and HCS were strongly localized in the trophoblast, while PZP was found diffusely in placental tissue (17); and (c) the placental weight has been found to be significantly correlated with maternal PAPP-A, PAPP-C, as well as HCS concentrations $(18,19) .^{3}$ In addition, the present study also failed to reveal binding of PAPP's by placental tissue residues, indicating that the elevated PAPP levels in placenta were not due to a receptor type of localization of these proteins synthesized elsewhere. Although these findings all point to the placenta as the site of synthesis of the PAPP's, isotopic tracer experiments may be necessary to conclusively establish this point.

The analytical data showed that the PAPP's are readily extractable from placenta by exposure to buffered saline, and indicated that the bulk of these proteins are removed by two extractions. However, it was clear from the absorption experiments that appreciable quantities of them remained bound to the placental insoluble residue, even after twelve extractions with PBS. Treatment of such residues with vigorous extracting solutions, such as those often used for solubilization of membrane proteins, failed to release significant amounts of additional PAPP's from the final placental sediments.

Quantitative estimates of the PAPP's in unwashed placental extracts indicated that $1 \mathrm{~g}$ placenta (wet weight) contained amounts of PAPP-A and PAPP-C approximating that found in $0.5 \mathrm{ml}$ of late pregnancy plasma. However, the data revealed that placenta is a

${ }^{3}$ Lin, T-M., S. P. Halbert, and W. N. Spellacy. Relation of obstetrical parameters to the concentrations of four pregnancy-associated plasma proteins at term in normal gestation. Submitted for publication. 
significantly richer source of PAPP-B and, especially, of HCS (PAPP-D).

The chorioamniotic membranes did not reveal quantities of the PAPP's beyond that due to their content of maternal plasma. These membranes can not, therefore, represent their site of synthesis.

The analytical data on the plasma proteins present in the crude unwashed placental extracts permitted an estimation to be made of the blood content of the placenta. Since each gram of placenta (wet weight) was found to contain about $0.2 \mathrm{ml}$ of plasma, this would represent roughly $0.36 \mathrm{ml}$ of whole blood. The $\mathrm{IgA}$ and $\mathrm{IgM}$ measurements indicated that $25 \%$ of this blood was maternally derived, and that $75 \%$ was, therefore, fetal in origin. From the placental volumes found (i.e., $1 \mathrm{~g}$ of placenta wet weight represented $0.78 \mathrm{ml}$ ), a $400-\mathrm{g}$ placenta occupying $312 \mathrm{ml}$ in volume would contain about $36 \mathrm{ml}$ of maternal blood, as well as $108 \mathrm{ml}$ of fetal blood (total of $144 \mathrm{ml}$ ). This value for the total blood volume of the placenta is in good agreement with estimates made by other methods $(20,21)$.

With regard to the total content of HCS found in the crude unwashed placenta, the above estimates, obtained immunologically, indicated an appreciably higher amount than has been suggested by others. Since $1 \mathrm{~g}$ wet weight of placenta was found to contain about 116 times the amount of HCS present in the reference pregnancy plasma pool (about $7 \mu \mathrm{g} / \mathrm{ml}$, see references 22 and 23 ), it can be estimated that $100 \mathrm{~g}$ of placenta contained about $81 \mathrm{mg}$ of HCS. This value is considerably greater than the $2-10 \mathrm{mg} \mathrm{HCS} / 100 \mathrm{~g}$ wet weight of placenta reported by Josimovich (24). Unfortunately, the methods used in arriving at this latter figure were not detailed, so the discrepancy cannot be accounted for at present. The large quantities of HCS in placenta may be required physiologically because of the very short halflife and rapid turnover of this hormone, i.e., about 20$30 \mathrm{~min}$. On the other hand, the much longer half-lives of PAPP-A and PAPP-C would not demand such rapid synthesis, and the relatively lower content of PAPP-A and $\mathrm{PAPP}-\mathrm{C}$ in placenta may reflect a synthetic rate adequate for maintaining plasma levels.

\section{ACKNOWLEDGMENTS}

These investigations were supported by a research grant from the National Institutes of Health (HD-5736).

\section{REFERENCES}

1. Gall, S. A., and S. P. Halbert. 1972. Antigenic constituents in pregnancy plasma which are undetectable in normal non-pregnant female or male plasma. Int. Arch. Allergy Appl. Immunol. 42: 503-515.

2. Lin, T-M., S. P. Halbert, D. Kiefer, W. N. Spellacy, and S. Gall. 1974. Characterization of four human pregnancy-associated plasma proteins. Am. J. Obstet. Gynecol. 118: 223-236.

3. Lin, T-M., S. P. Halbert, and W. N. Spellacy. 1974. Measurement of pregnancy-associated plasma proteins during human gestation. J. Clin. Invest. 54: 576-582.

4. Lin, T. M., S. P. Halbert, W. N. Spellacy, and S. Gall. 1974. Measurement of pregnancy-associated plasma proteins (PAPP's) during gestation and their immunological identification. Fed. Proc. 33: 282. (Abstr.)

5. Bohn, H. 1971. Nachweis und Charakterisierung von Schwangerschafts-proteinen in der menschlichen Placenta, sowie ihre quantitative immunologische Bestimmung im serum schwangerer Frauen. Arch. Gynaekol. 210: 440-457.

6. Lin, T. M., S. P. Halbert, D. Kiefer, and W. N. Spellacy. 1974. Three pregnancy-associated human plasma proteins: purification, monospecific antiserum and immunological identification. Int. Arch. Allergy Appl. Immunol. 47 : 35-53.

7. Lin, T. M., S. P. Halbert, W. N. Spellacy, and S. Gall. 1975. Human pregnancy-associated plasma proteins during the post-partum period. Am. J. Obstet. Gynecol. In press.

8. Lin, T. M., and S. P. Halbert. 1975. Immunological comparison of various human pregnancy-associated plasma proteins. Int. Arch. Allergy Appl. Immunol. 48: 101-115.

9. Beckman, L., B. von Schoultz, and T. Stigbrand. 1971. Induction of the "pregnancy zone" protein by oral contraceptives. Acta Obstet. Gynecol. Scand. 50: 369-371.

10. Horne, C. H. W., A. L. C. McLay, H. B. Tavadia, I. Carmichael, A. C. Mallison, A. A. C. Yeung-Laiwah, M. A. Thomas, and R. N. M. MacSween. 1973. Studies on pregnancy-associated globulin. Clin. Exp. Immunol. 1.3: $603-611$

11. Dunston, G. M., and H. Gershowitz. 1974. A hormonally influenced human serum globulin: elevation of $\mathrm{Xh}$ by estrogen. J. Lab. Clin. Med. 84: 187-190.

12. Stimson, W. H. 1973. Quantitation of a new serum alpha-macroglobulin in pregnant preeclamptic and contraceptive steroid treated subjects. IRCS Int. Res. Commun. Syst. Med. Sci. (73-3) 17-1-3.

13. Berne, B. H. 1973. Alpha-2 pregnoglobulin (pregnancyzone protein)-a unique macroglobulin elevated in pregnancy, contraception and cancer. Fed. Proc. 32: 677. (Abstr.)

14. von Schoultz, B. 1974. A quantitative study of the pregnancy zone protein in the sera of pregnant and puerperal women. Am. J. Obstet. Gynecol. 119: 792-797.

15. Lin, T. M., S. P. Halbert, and D. Kiefer. 1972. The cardiac auto-immune system. VI. Purification and further characterization of one of the human heart proteins which cross-react with rabbit anti-rabbit heart auto-antibodies. Int. Arch. Allergy Appl. Immunol. 43: 269-288.

16. Stimson, W. H., and J. C. Blackstock. 1975. Synthesis of a pregnancy-associated $\alpha$-macroglobulin by human leucocytes. Experientia (Basel). 31: 371-373.

17. Lin, T. M., S. P. Halbert, and D. Kiefer. 1975. Pregnancy-associated plasma proteins (PAPP's) in human placenta. Fed. Proc. 34: 339. (Abstr.)

18. Tatra, G., P. Placheta, and G. Breitenecker. 1975. Schwangerschaftsspezifisches $\beta_{1}$-glykoprotein (SP-1): klinische Aspekte. Wien. Klin. Wochenschr. 87: 279281.

19. Spellacy, W. N., W. C. Buhi, J. D. Schram, S. A. 
Birk, and S. A. McCreary. 1971. Control of human chorionic somatomammotropin levels during pregnancy. Obstet. Gynecol. 37 : 567-573.

20. Yao, A. C., M. Moinian, and J. Lind. 1969. Distribution of blood between infant and placenta after birth. Lancet. 2: 871-873.

21. Morris, J. A., R. F. Hustead, R. G. Robinson, G. L. Haswell, C. A. Morgan, and A. Gobuty. 1974. Measurement of fetoplacental blood volume in the human previable fetus. Am. J. Obstet. Gynecol. 118: 927-934.
22. Saxena, B. N. 1971. Protein polypeptide hormones of the human placenta. Vitam. Horm. 29: 95-151.

23. Spellacy, W. N., E. S. Teoh, W. C. Buhi, S. A. Birk, and S. A. McCreary. 1971. Value of human chorionic somatomammotropin in managing high-risk pregnancies. Am. J. Obstet. Gynecol. 109: 588-598.

24. Josimovich, J. B. 1968. The human placental lactogen. In Clinical Endocrinology. II. E. B. Astwood and C. E. Cassidy, editors. Grune \& Stratton, Inc., New York. 658-664. 